\title{
Calcium- and Calmodulin-mediated Protein Synthesis and Protein Phosphorylation during Germination, Growth and Protease Production by Metarhizium anisopliae
}

\author{
By RAYMOND J. ST LEGER, * DONALD W. ROBERTS AND \\ RICHARD C. STAPLES \\ Boyce Thompson Institute for Plant Research, Tower Road, Cornell University, Ithaca, \\ New York 14853, USA
}

(Received 1 February 1989; revised 10 May 1989; accepted 22 May 1989)

\begin{abstract}
Protein synthesis and phosphorylation were studied in Metarhizium anisopliae. Calmodulin ( $\mathrm{CaM})$ and $\mathrm{CaM}$-target proteins were found in conidia and germlings of $M$. anisopliae. Conidial uptake of $\left[{ }^{35} \mathrm{~S}\right] \mathrm{methionine}$ and $\left[{ }^{32} \mathrm{P}\right]$ orthophosphate and their incorporation into protein was massively reduced by known antagonists of $\mathrm{CaM}$, depletion of intracellular $\mathrm{Ca}^{2+}$ by ionophoresis or antagonism of $\mathrm{Ca}^{2+}$ with $\mathrm{La}^{3+}$, agents which prevented nuclear division and germination. Inhibitors of $\mathrm{C}$-kinase $(\mathrm{H}-7)$ and cyclic-nucleotide-dependent kinase $(\mathrm{H}-8)$ selectively repressed phosphorylation of a $27 \mathrm{kDa}$ protein but did not affect the profile of protein synthesis nor change germination frequency and mode of growth. By contrast, inhibitor and ionophoresis studies on mycelia showed that extracellular secretion of proteins but not protein synthesis was $\mathrm{Ca}^{2+}$-dependent. Protein phosphorylation in mycelia was also $\mathrm{Ca}^{2+}$-dependent/ $\mathrm{CaM}$-independent. CaM antagonists stimulated phosphorylation of 17 and $33 \mathrm{kDa}$ polypeptides. Most proteins in mycelia were phosphorylated at serine and threonine residues. However, immunoblotting with anti-phosphotyrosine serum revealed prominent bands at 34.5 and $38 \mathrm{kDa}$. The $38 \mathrm{kDa}$ protein was detectable on isolated plasma membranes. Our results suggest that $M$. anisopliae possesses stimulus transduction pathways similar to those known in plant and animal systems.
\end{abstract}

\section{INTRODUCTION}

Protein phosphorylation is recognized as the primary mechanism for the transduction of extracellular stimulants into intracellular events (Cohen, 1982; Nestler et al., 1984). In animal systems, receptors for a variety of growth factors are themselves protein-tyrosine kinases (Sibley et al., 1987). Furthermore, in higher eukaryotes the biochemical events produced by cyclic AMP (cAMP) are accomplished by activation of cAMP-dependent protein kinase (Krebs \& Beavo, 1979). $\mathrm{Ca}^{2+}$ also regulates a diverse array of cellular functions by its ability to activate several protein kinases (Cohen, 1985). Many of the effects of $\mathrm{Ca}^{2+}$ are mediated by the $\mathrm{Ca}^{2+}$-binding protein calmodulin $(\mathrm{CaM})$, which, in its $\mathrm{Ca}^{2+}$-activated form, is able to activate or inactivate a number of enzymes including protein kinases and at least one phosphoprotein phosphatase (Nairn et al., 1985).

Information on the role(s) of $\mathrm{Ca}^{2+}$ and $\mathrm{CaM}$ in growth and development of fungi is sparse and indirect (Schmid \& Harold, 1988; Giannini et al., 1988). The presence in Neurospora crassa of CaM (Ortega Perez et al., 1981), $\mathrm{Ca}^{2+}$ and CaM-dependent protein kinases (Ortega Perez et al.,

Abbreviations: Anti-PTYR antibodies, anti-phosphotyrosine antibodies; Br-A23187, 4-bromo-A23187; CaM, calmodulin; DAPI, 4,6-diamidino-2-phenylindole; RIA, radioimmunoassay; SDB(A), Sabouraud dextrose broth (agar); TPA, 12-O-tetradecanoylphorbol-13-acetate; YEM, yeast extract medium. 
1983; Van Tuinen et al., 1984) and a $\mathrm{Ca}^{2+}$ - and phospholipid-dependent protein kinase (protein kinase C) (Favre \& Turian, 1987) indicates that $\mathrm{Ca}^{2+}$ has a regulatory role in this fungus. CaM appears to be ubiquitous in fungi (Muthukumar et al., 1987) and is crucial in yeasts where it may be involved in the normal function of microtubules (Eilam \& Chernichovsky, 1988). No distinctive function has yet been assigned to $\mathrm{CaM}$ in filamentous fungi.

If fungal cells use $\mathrm{Ca}^{2+}$ as a second messenger in a manner similar to animal cells (Carafoli, 1987) and plant cells (Hepler \& Wayne, 1985), then protein-phosphorylation events should be sensitive to effectors of intracellular levels of $\mathrm{Ca}^{2+}$ and $\mathrm{Ca}^{2+}$-binding proteins such as $\mathrm{CaM}$. In this paper we report that calcium and $\mathrm{CaM}$ are required for protein synthesis and phosphorylation during germination of conidia of the entomopathogenic fungus Metarhizium anisopliae. We also investigated phosphorylation events during vegetative growth in conditions favourable to secretion of high levels of alkaline protease ( $\operatorname{Pr} 1)$, a pathogenicity determinant in M. anisopliae (St Leger et al., 1988). Prl production was used as a model system to investigate the effects of $\mathrm{Ca}^{2+}$ on protein synthesis and processing, our eventual aim being to study the regulation of transcription and translation in the fungal cell by manipulating cellular levels of secondary messengers such as $\mathrm{Ca}^{2+}$ and cAMP.

\section{METHODS}

Organism and growth. The fungal isolate (Metarhizium anisopliae ME1) and culture media were described by St Leger et al. (1987). Germination experiments were done in yeast extract media (YEM; $0.0125 \%$ ) (St Leger et al., $1989 a$ ).

Chemicals. Affinity purified anti-phosphotyrosine antibodies (anti-PTYR antibodies) were a generous gift from Dr Jean Y. J. Wang (University of California, La Jolla, CA, USA). Other reagents were procured as follows: biotinylated $\mathrm{CaM}$ (Biomedical Technologies); ${ }^{125}$ I-Protein $\mathrm{A}$ and $\left[{ }^{35} \mathrm{~S}\right] \mathrm{methionine}$ (ICN); carrier-free [32P]phosphoric acid and the CaM radioimmunoassay kit (Amersham); nitrocellulose (BA85, Schleicher and Schuell); protein kinase inhibitor H-8 (Seikagaku America); Sabouraud dextrose broth (SDB; Oxoid). Other chemicals were from Sigma.

Immunological detection of phosphotyrosine-containing proteins. Plasma membranes (about $30 \mu \mathrm{g}$ protein) were vigorously shaken in $10 \mathrm{mM}-\mathrm{Tris} / \mathrm{HCl}(\mathrm{pH} 7.5)$ with or without Triton X-100 $(0.1 \%, \mathrm{v} / \mathrm{v})($ final volume $50 \mu \mathrm{l})$. After $15 \mathrm{~min}$ an equal volume of electrophoresis sample buffer (Laemmli, 1970) was added and the preparation was heated for $5 \mathrm{~min}$ in a boiling water-bath. The samples were centrifuged in an Eppendorf centrifuge and the supernatants were analysed by SDS-PAGE $(13 \%, \mathrm{w} / \mathrm{v}$, acrylamide). Proteins were electrophoretically transferred from the gel to nitrocellulose and probed with anti-PTYR antibodies, followed by ${ }^{125}$ I-protein A. Except for the specificity of the antibodies, the procedure was similar to that described previously (St Leger $e t$ al., 1989b). Bovine serum albumin $(3 \%, \mathrm{w} / \mathrm{v})$ was used as blocking agent (Burnette, 1981). To differentiate between phosphorylation on serine and threonine residues versus tyrosine residues, gels were incubated in $1 \mathrm{M}-\mathrm{NaOH}$ at $55^{\circ} \mathrm{C}$ (Cooper \& Hunter, 1981).

CaM levels in conidia and mycelia. CaM levels were determined with a CaM-specific radioimmunoassay (RIA) kit. The specificity of this assay for fungal CaMs has been demonstrated previously (Muthukumar et al., 1987).

Washed conidia (500 mg) harvested from 10-d-old SDA cultures (St Leger et al., 1989a) and acid-washed sand $(500 \mathrm{mg})(<0.3 \mathrm{~mm}$ diameter $)$ were vortexed under liquid nitrogen in a $50 \mathrm{ml}$ screwtop centrifuge tube for five periods of $5 \mathrm{~min}$ each. The fractured conidia and sand were then suspended in the Amersham CaM-extraction buffer supplemented with $3 \mathrm{mM}$-EDTA, $3 \mathrm{~mm}$-EGTA and $0.5 \mathrm{~mm}$-PMSF. All subsequent steps were as described in the RIA kit.

Mycelium ( $1 \mathrm{~g}$ wet $\mathrm{wt}$ ) from $32 \mathrm{~h}$ SDB cultures was washed three times with $0.2 \mathrm{M}$-potassium phosphate buffer (pH 6.5), resuspended in the amended Amersham extraction buffer and disrupted for $3 \mathrm{~min}$ at 4000 r.p.m. in a Braun MSK homogenizer with $0.3 \mathrm{~mm}$ diameter glass beads. All subsequent steps were as described in the RIA kit.

The concentration of Metarhizium $\mathrm{CaM}$ was determined from a standard curve constructed using the rat $\mathrm{CaM}$ provided in the RIA kit. Results are given as $\mu \mathrm{g}$ rat equivalent $\mathrm{CaM}(\mathrm{mg} \text { protein })^{-1} \pm \mathrm{SE}(n=5)$. Each result is the mean of five determinations made from different batches of conidia or mycelia from different flasks.

Labelling of CaM-binding proteins in protein blots (after Billingsley et al., 1985). Proteins were isolated and separated by SDS-PAGE (13\%, w/v, acrylamide) (St Leger et al., 1989a), transferred to nitrocellulose and probed for $1 \mathrm{~h}$ with biotinylated $\mathrm{CaM}\left(10 \mu \mathrm{g} \mathrm{ml}^{-1}\right)$ in buffer $\left(50 \mathrm{mM}-\mathrm{Tris} / \mathrm{HCl}, \mathrm{pH} 7 \cdot 4,300 \mathrm{mM}-\mathrm{NaCl}, 1 \mathrm{~mm}-\mathrm{CaCl}_{2}, 5 \%\right.$, $\mathbf{w} / \mathbf{v}$, nonfat dry milk). Specific CaM-binding proteins were visualized with avidin-alkaline-phosphatase and appropriate chromogens (Billingsley et al., 1985). In order to demonstrate $\mathrm{Ca}^{2+}$-dependence of binding, $5 \mathrm{mM}$ EGTA was used for certain blots instead of $1 \mathrm{mM}-\mathrm{Ca}^{2+}$. 
Uptake of $\left[{ }^{35} S\right]$ methionine and ${ }^{32} P$. Conidia $\left(1 \times 10^{6} \mathrm{ml}^{-1}\right)$ were incubated with shaking $(75 \mathrm{r} . \mathrm{p} . \mathrm{m}$.) for up to $5 \mathrm{~h}$ at $27^{\circ} \mathrm{C}$ in $50 \mathrm{ml} \mathrm{YEM}$ containing $20 \mu \mathrm{Ci}(740 \mathrm{kBq})$ carrier-free $\left[{ }^{32} \mathrm{P}\right]$ phosphoric acid or [ $\left.{ }^{35} \mathrm{~S}\right] \mathrm{methionine}$ in the presence or absence of $\mathrm{R} 24571$ or $\mathrm{La}^{3+}$. At set intervals a $200 \mu \mathrm{l}$ sample of each conidial suspension was spotted directly on to a glass-fibre (Whatman GF/C) disc. The conidia were washed (five $\times 20 \mathrm{~cm}^{3}$ ) with $0 \cdot 2 \mathrm{M}$-potassium phosphate buffer containing $\mathrm{KCl}(0.2 \mathrm{M})$ and Tween $80(0.05 \%)$. The conidia were further washed in $95 \%$ ethanol (three $\times 10 \mathrm{~cm}^{3}$ ), dried and counted with their filters in $6 \mathrm{ml}$ of Cytoscint (ICN) cocktail using a Beckman LS5801 scintillation counter. This determination represents the total uptake of $\left[{ }^{35} \mathrm{~S}\right]$ methionine or $\left[{ }^{32} \mathrm{P}\right]$ orthophosphate by conidia.

${ }^{32} \mathrm{P}$ and ${ }^{35} \mathrm{~S}$ incorporation into proteins. Conidia $\left(1 \times 10^{6} \mathrm{ml}^{-1}\right)$ or standard fungal inocula $(1 \mathrm{~g}$ wet wt $)$ from $32 \mathrm{~h}$ SDB cultures were incubated with shaking (75 r.p.m.) for up to $10 \mathrm{~h}$ at $27^{\circ} \mathrm{C}$ in $10 \mathrm{ml} \mathrm{YEM}$ or chitin buffer media containing $0.2 \mathrm{mCi}(7.4 \mathrm{MBq})$ carrier-free [ $\left.{ }^{32} \mathrm{P}\right]$ phosphoric acid or $\left[{ }^{35} \mathrm{~S}\right]$ methionine in the presence or absence of drugs. Proteins secreted into growth media were precipitated by incubating overnight at $-20^{\circ} \mathrm{C}$ with 3 vols $0 \cdot 1 \mathrm{M}$ ammonium acetate in methanol. Proteins were collected by centrifugation $(10000 \mathrm{~g}, 10 \mathrm{~min})$ and redissolved in water. Proteins were extracted from conidia or mycelia and prepared for electrophoresis as described below.

$S D S-P A G E$. Total cellular proteins were extracted from conidia or mycelia as previously described (St Leger et $a l ., 1989 b$ ) except that the extraction buffer was supplemented with the phosphatase inhibitors $\mathrm{NaF}(10 \mathrm{mM})$ and sodium molybdate $(10 \mathrm{mM})$. Proteins were processed for and subjected to SDS-PAGE (Laemmli, 1970). Unless stated otherwise, acrylamide concentrations of 8 or $15 \%(w / v)$ were used to gain maximum resolution for molecular mass estimates of high and low molecular mass polypeptides, respectively. Radiolabelled proteins were detected by autoradiography (St Leger et al., 1989 b).

Plasma membrane preparation. Plasma membranes were isolated from mycelia from $32 \mathrm{~h}$ SDB cultures by $\beta$-glucuronidase digestion of the cell wall, gentle homogenization and differential centrifugation (Bowman \& Bowman, 1988). Contamination by endoplasmic reticulum was removed by sucrose gradient centrifugation (Borgeson \& Bowman, 1983). The membrane-associated ATPase, assayed by the method of Serrano (1978), was orthovanadate-sensitive, oligomycin-insensitive, indicating that the plasma membranes were free from mitochondrial contamination (Goffeau \& Slayman, 1981). The absence of nucleic acids, extracted by the guanidium/ hot phenol method (Maniatis et al., 1982) and assayed at $260 \mathrm{~nm}$, indicates that the membranes were free of cytoplasmic contamination.

Miscellaneous. Nuclei were stained using DAPI as described previously (St Leger et al., 1989a). Chymoelastase activity $(\mathrm{Prl})$ was determined using succinyl-alanine-alanine-proline-phenylalanine $p$-nitroanilide as substrate ( $\mathrm{St}$ Leger et al., 1987). Protein concentration was determined by the method of Bradford (1976). $\mathrm{Ca}^{2+}$ antagonists were added to cultures from stock solutions in distilled water $\left[\mathrm{La}\left(\mathrm{NO}_{3}\right)_{3}, \mathrm{CaCl}_{2}\right]$, ethanol (ionophores) or dimethylsulphoxide (CaM antagonists). The final concentration of ethanol or dimethylsulphoxide was $\leqslant 0.04 \%$ which had no effect on protein synthesis or phosphorylation in controls.

\section{RESULTS}

\section{Detection of CaM and CaM-binding proteins}

$\mathrm{CaM}$ levels in ungerminated conidia, germlings ( $13 \mathrm{~h}$ YEM cultures) and mycelia ( $32 \mathrm{~h}$ SDB cultures) were $4.6 \pm 1.05,2.9 \pm 0.75$ and $4.1 \pm 0.61 \mu \mathrm{g}$ rat equivalent $\mathrm{CaM}$ (mg total protein) ${ }^{-1}$ respectively ( $n=$ five independent measurements).

Six prominent CaM-binding proteins $(37 \cdot 5,42,44,69 \cdot 5,78$ and $84 \mathrm{kDa})$ were detected in conidia and germlings (Fig. 1). Binding of biotinylated CaM was prevented by replacing $\mathrm{Ca}^{2+}$ with EGTA, indicating the $\mathrm{Ca}^{2+}$ dependence of these interactions. The exception was the $37.5 \mathrm{kDa}$ protein which showed low binding with EGTA. Fifteen relatively minor $\mathrm{Ca}^{2+}$ dependent CaM-binding proteins $(18-35 \mathrm{kDa})$ were also detected.

\section{Effect of $\mathrm{CaM}$ and $\mathrm{Ca}^{2+}$ antagonists on germination}

A range of structurally diverse agents known to act as antagonists of $\mathrm{CaM}$ function were potent inhibitors of germination of conidia in YEM. The rank order of effectiveness of the CaM antagonists in terms of $\mathrm{IC}_{50}$ values $(\mu \mathrm{M})$ (the concentration of inhibitor reducing germination by $50 \%$ ) and the binding affinity of the antagonists for CaM $\left[K_{\mathrm{i}}(\mu \mathrm{m})\right.$ values from Asano et al., 1985] were: compound 48/80, $1 \cdot 1\left(K_{\mathrm{i}} 0 \cdot 3\right) ; \mathrm{R} 24571,1 \cdot 4\left(K_{\mathrm{i}} 0 \cdot 3\right)$; trifluoperazine, $14\left(K_{\mathrm{i}} 1\right) ; \mathrm{W}-7$, $23\left(K_{\mathrm{i}} 11\right)$ and W-5, $>200\left(K_{\mathrm{i}} 90\right)$. This correlation between effectiveness and CaM-binding affinity is convincing evidence for the specificity of action of the antagonists (Roufogalis et al., 1982; Asano \& Stull, 1985). Those conidia which did germinate produced short, broad, frequently asymmetric germ-tubes. Examination of affected germlings $\left(1.4 \mu \mathrm{g} \mathrm{ml}^{-1}\right.$ of the CaM 


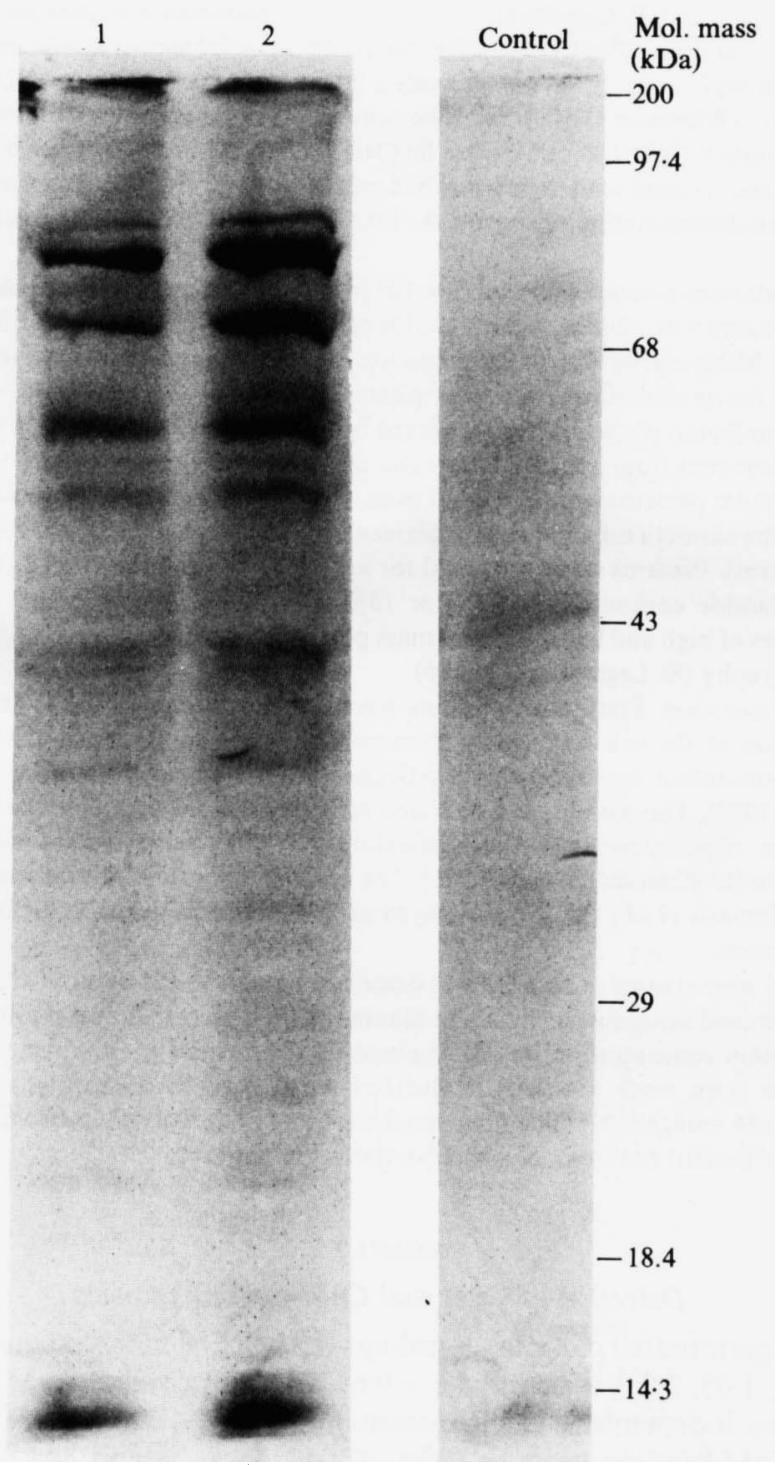

Fig. 1. Binding of biotinylated $\mathrm{CaM}$ to $\mathrm{CaM}-$ binding proteins. Proteins $(100 \mu \mathrm{g})$ from conidia (1) and germlings (2) were subjected to SDS-PAGE (13\%, w/v, acrylamide), electroblotted on to nitrocellulose, incubated with biotinylated $\mathrm{CaM}$ in the presence of $\mathrm{Ca}^{2+}$, and the blots developed with avidinalkaline-phosphatase. In incubation mixtures containing 5 mM-EGTA, little binding of biotinylated $\mathrm{CaM}$ was detected (control, germling proteins).

antagonist R24571) after staining with DAPI showed that nuclear division had not occurred. However, $43 \%$ of conidia had swollen from $4 \times 2.5 \mu \mathrm{m}$ to about $8 \times 3.5 \mu \mathrm{m}$, an event that precedes normal germination (Dillon \& Charnley, 1989). Increasing the concentration of R24571 $\left(7 \mu \mathrm{g} \mathrm{ml}^{-1}\right)$ further repressed the frequency of spore swelling $(<10 \%)$.

Incorporation into growth media (YEM) of the $\mathrm{Ca}^{2+}$ chelator EGTA or plasmalemma $\mathrm{Ca}^{2+}$ channel blockers (nifedipine or verapamil) had no effect on germination, indicating that this process does not require an influx of $\mathrm{Ca}^{2+}$. However, without extracellular $\mathrm{Ca}^{2+}(3 \mathrm{mM}$-EGTA) germ-tube growth was limited to $85-130 \mu \mathrm{m}$ as compared with $>400 \mu \mathrm{m}$ after $30 \mathrm{~h}$ in unmodified YEM. 
Table 1. Effect of $\mathrm{Ca}^{2+}$ antagonists and ionophores on germination and germ-tube growth

Conidia were incubated for $14 \mathrm{~h}$ with inhibitor in YEM, pH 6.8.

\begin{tabular}{|c|c|c|}
\hline Treatment & $\begin{array}{l}\text { Germination }(\%) \\
(n=300)\end{array}$ & $\begin{array}{l}\text { Mean germ-tube growth }(\mu \mathrm{m}) \\
( \pm \mathrm{SE}, n=100)\end{array}$ \\
\hline None & 84 & $17 \pm 6 \cdot 3$ \\
\hline $\mathrm{CaCl}_{2}(1 \mathrm{mM})$ & 85 & $19 \pm 7 \cdot 1$ \\
\hline EDTA $(5 \mathrm{mM})$ & 82 & $16 \pm 4 \cdot 2$ \\
\hline A23187 $(2 \mu \mathrm{M})$ & 72 & $12 \pm 6.3$ \\
\hline A23187 $(2 \mu \mathrm{M})+\mathrm{CaCl}_{2}(1 \mathrm{mM})$ & 87 & $28 \pm 6.7$ \\
\hline A23187 $(2 \mu \mathrm{M})+$ EGTA $(5 \mathrm{mM})$ & 65 & $8 \pm 2 \cdot 3$ \\
\hline A23187 $(6 \mu \mathrm{M})$ & 54 & $7 \pm 0.4$ \\
\hline A23187 $(6 \mu \mathrm{M})+$ EGTA $(5 \mathrm{mM})$ & 8 & $6 \pm 2 \cdot 0$ \\
\hline $\mathrm{A} 23187(10 \mu \mathrm{M})+\mathrm{Ca}^{2+}(1 \mathrm{mM})$ & 75 & $14 \pm 2.5$ \\
\hline $\mathrm{Br}-\mathrm{A} 23187(5 \mu \mathrm{M})$ & 81 & $13 \pm 3 \cdot 6$ \\
\hline $\mathrm{Br}-\mathrm{A} 23187(5 \mu \mathrm{M})+\mathrm{CaCl}_{2}(1 \mathrm{mM})$ & 83 & $27 \pm 8 \cdot 3$ \\
\hline $\mathrm{Br}-\mathrm{A} 23187(5 \mu \mathrm{M})+\mathrm{EGTA}(5 \mathrm{mM})$ & 62 & $10 \pm 4 \cdot 0$ \\
\hline Br-A23187 $(10 \mu \mathrm{M})+$ EGTA $(5 \mathrm{mM})$ & 12 & $8 \pm 0.3$ \\
\hline $\mathrm{La}\left(\mathrm{NO}_{3}\right)_{3}(10 \mu \mathrm{M})$ & 73 & $15 \pm 3 \cdot 2$ \\
\hline$(25 \mu \mathrm{M})$ & 54 & $9 \pm 1.4$ \\
\hline$(50 \mu \mathrm{M})$ & 2 & 5 \\
\hline Fluorescein isothiocyanate $(150 \mu \mathrm{M})$ & 80 & $16 \pm 6.8$ \\
\hline Ryanodine $(50 \mu \mathrm{M})$ & 81 & $18 \pm 5.4$ \\
\hline
\end{tabular}

Ionophoresis experiments were done using the divalent cation ionophore $\mathrm{A} 23187$ or the $\mathrm{Ca}^{2+}$ selective ionophore $\mathrm{Br}-\mathrm{A} 23187$ (Deber et al., 1985). In the presence of $\mathrm{Ca}^{2+}$, high concentrations of ionophore did not affect germination frequency. Depleting intracellular $\mathrm{Ca}^{2+}$ levels (A23187 + EGTA or Br-A23187 + EGTA) reduced germination by an extent dependent on the concentration of the ionophore (Table 1). A similar effect was produced by low concentrations of the $\mathrm{Ca}^{2+}$ antagonist $\mathrm{La}^{3+}$ (Anghileri, 1987). At higher concentrations $\mathrm{La}^{3+}(>50 \mu \mathrm{M})$ was a potent inhibitor of germination (Table 1). The inhibitory effects of $\mathrm{R} 24571$ or $\mathrm{La}^{3+}$ on germination were not reduced by extending the duration of incubation up to $4 \mathrm{~d}$. Specific antagonists of $\mathrm{Ca}^{2+}$ transport across endoplasmic reticulum (ryanodine and fluorescein isothiocyanate) did not affect germination frequency.

\section{Effect of $\mathrm{Ca}^{2+}$ antagonists on the uptake of $\left[{ }^{32} \mathrm{P}\right]$ orthophosphate and $\left[{ }^{35}\right.$ S $]$ methionine and their incorporation into proteins during germination}

When conidia were incubated in YEM for $10 \mathrm{~h}(70 \%$ germination frequency) in the presence of $\left[{ }^{35} \mathrm{~S}\right]$ methionine or $\left[{ }^{32} \mathrm{P}\right]$ phosphoric acid, 60 and 32 radiolabelled proteins were detected respectively (Fig. 2). Most of the newly made proteins detected using $\left[{ }^{35}\right.$ S $]$ methionine as precursor could also be identified in ungerminated conidia using Coomassie blue stain (Fig. 2). Some of the major [ ${ }^{35} \mathrm{~S}$ ]methionine- and ${ }^{32} \mathrm{P}$-labelled polypeptides possessed the same molecular masses; amongst the more prominent were bands at 16, 19.5, 20.5, 21.5, 25.5, 33, 39 (Fig. 2), 79.2 and $98.4 \mathrm{kDa}$ [estimated from an SDS-PAGE gel $(8 \%$, w/v, acrylamide); data not shown]. Compound R24571 $\left(2.8 \mu \mathrm{g} \mathrm{ml}^{-1}\right)$ and $\mathrm{La}^{3+}(50 \mu \mathrm{M})$ repressed uptake of [ ${ }^{35}$ S]methionine over $5 \mathrm{~h}$ by $91 \%\left(2.6 \pm 0.5\right.$ c.p.m. $\left.\times 10^{-3}\right)$ and $89 \%\left(3.3 \pm 0.3\right.$ c.p.m. $\left.\times 10^{-3}\right)$ respectively compared with controls $\left(28.8 \pm 2.5\right.$ c.p.m. $\times 10^{-3}$; results expressed as $\left.\bar{X} \pm \mathrm{SD}, n=3\right)$. Likewise, compound $\mathrm{R} 24571$ and $\mathrm{La}^{3+}$ repressed uptake of [32P]orthophosphate by $95 \%\left(0 \cdot 5 \pm 0 \cdot 1 \mathrm{c} . \mathrm{p} . \mathrm{m} . \times 10^{-3}\right)$ and $87 \%\left(1 \cdot 3 \pm 0 \cdot 1\right.$ c.p.m. $\left.\times 10^{-3}\right)$ respectively (controls $10 \pm 0.8$ c.p.m. $\times 10^{-3} ; \bar{X} \pm \mathrm{SD}, n=3$ ). Similar repression was obtained by depleting intracellular $\mathrm{Ca}^{2+}(\mathrm{Br}-\mathrm{A} 23187(10 \mu \mathrm{M})+$ EGTA $(5 \mathrm{mM})$. SDS-PAGE analysis confirmed that R24571 $\left(2 \cdot 8 \mu \mathrm{g} \mathrm{ml}^{-1}\right), \mathrm{La}^{3+}(50 \mu \mathrm{M})$ and ionophoresis (EGTA + Br-A23187) entirely prevented incorporation of [ $\left.{ }^{32} \mathrm{P}\right]$ orthophosphate (Fig. 3) or ${ }^{35}$ S $]$ methionine into proteins (data not shown). None of the proteins stained by Coomassie blue were selectively degraded during treatment of conidia with R24571 (Fig. 2, lane 2). Other treatments which might perturb intracellular $\mathrm{Ca}^{2+}$ gradients, e.g. $\mathrm{Br}-\mathrm{A} 23187+\mathrm{Ca}^{2+}$ or $\mathrm{H}-7$ [1-(5-isoquinolinesulphonyl)-2-methylpiperazine dihydrochloride, the $\mathrm{H}$-series inhibitor 


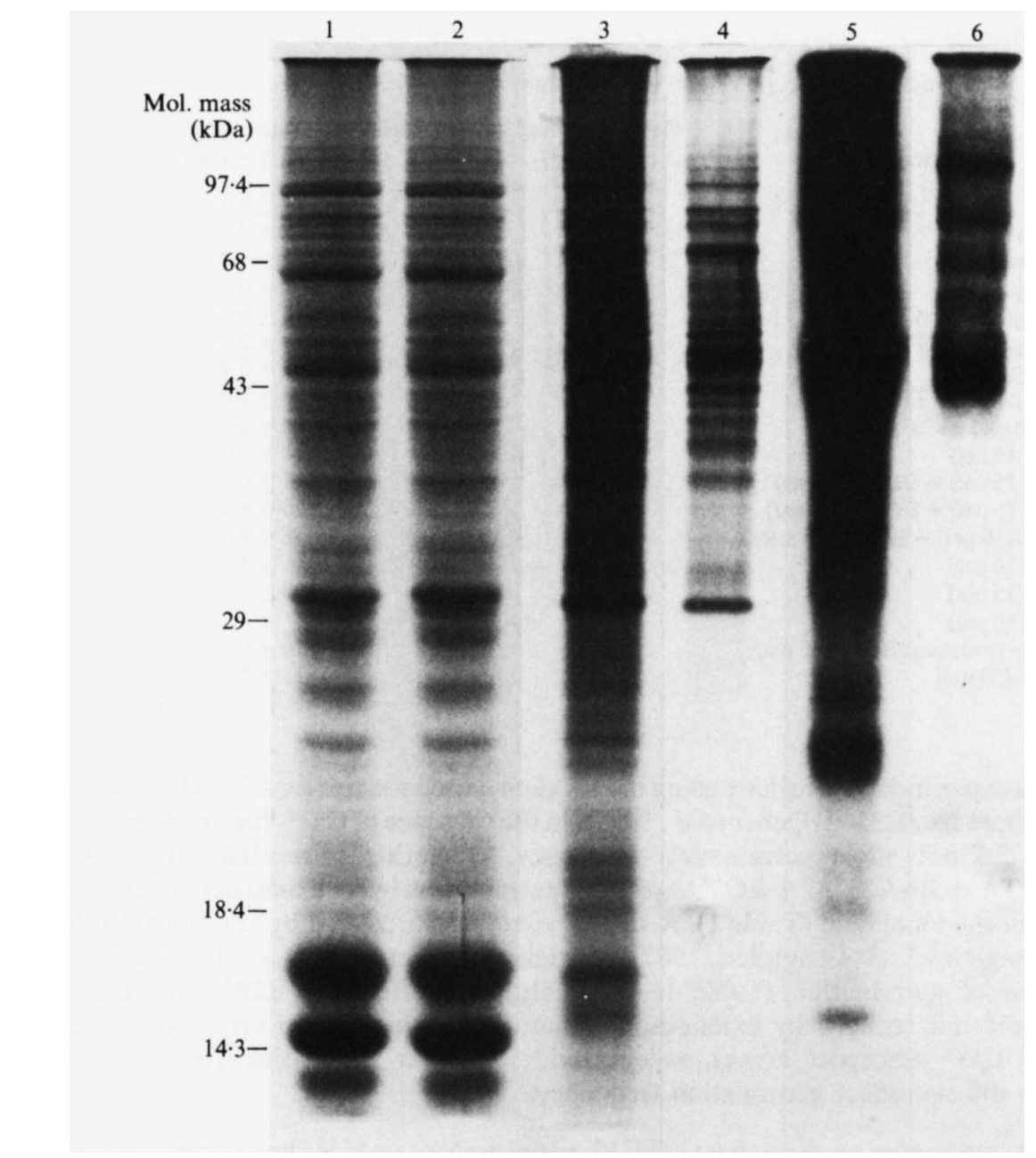

Fig. 2. SDS-PAGE (13\%, w/v, acrylamide) analysis of newly synthesized proteins during germination of conidia of $M$. anisopliae. 1, Proteins $(80 \mu \mathrm{g})$ from ungerminated conidia stained with Coomassie blue dye. 2, Stained proteins $(80 \mu \mathrm{g})$ from conidia incubated $(10 \mathrm{~h})$ in YEM containing R24571 $(2 \mu \mathrm{M}) .3,4,5$, 6 , Autoradiographs of incorporation of ${ }^{35}$ S $]$ methionine $(3,4)$ or ${ }^{32} \mathrm{P}(5,6)$ into proteins $(30 \mu \mathrm{g})$ from conidia incubated for $10 \mathrm{~h}$ at $27^{\circ} \mathrm{C}$ in YEM. Autoradiographs were incubated for $12 \mathrm{~h}(4,6)$ or $24 \mathrm{~h}$ $(3,5)$.

with highest affinity for protein kinase C (Hidaka \& Tanaka, 1987)] did not affect total uptake of [ ${ }^{32} \mathrm{P}$ ]orthophosphate but selectively repressed phosphorylation at $15 \cdot 7,36$ and $38 \mathrm{kDa}$. In addition, $\mathrm{H}-7$ repressed phosphorylation at $27 \mathrm{kDa}$ (Fig. 3). These effects were not correlated with a change in the profile of protein synthesis.

\section{Effect of $\mathrm{Ca}^{2+}$ antagonists on protein synthesis and extracellular production of Prl}

Extracellular $\operatorname{Pr} 1$ is formed de novo within $3 \mathrm{~h}$ of mycelia being transferred from SDB (catabolite repression; Prl not produced) to a medium containing chitin (Table 2). Production of extracellular $\operatorname{Pr} 1$ was unaffected by the presence of $\mathrm{H}-7, \mathrm{H}-8$ [ $N$-(2-methylamino)ethyl-5-isoquinolinesulphonamide dihydrochloride, the $\mathrm{H}$-series inhibitor with highest affinity for cyclicnucleotide-dependent kinases (Hidaka \& Tanaka, 1987)], nifedipine and EGTA. Antagonists of CaM (compound 48/80 and R24571) were also without effect, even at concentrations tenfold 


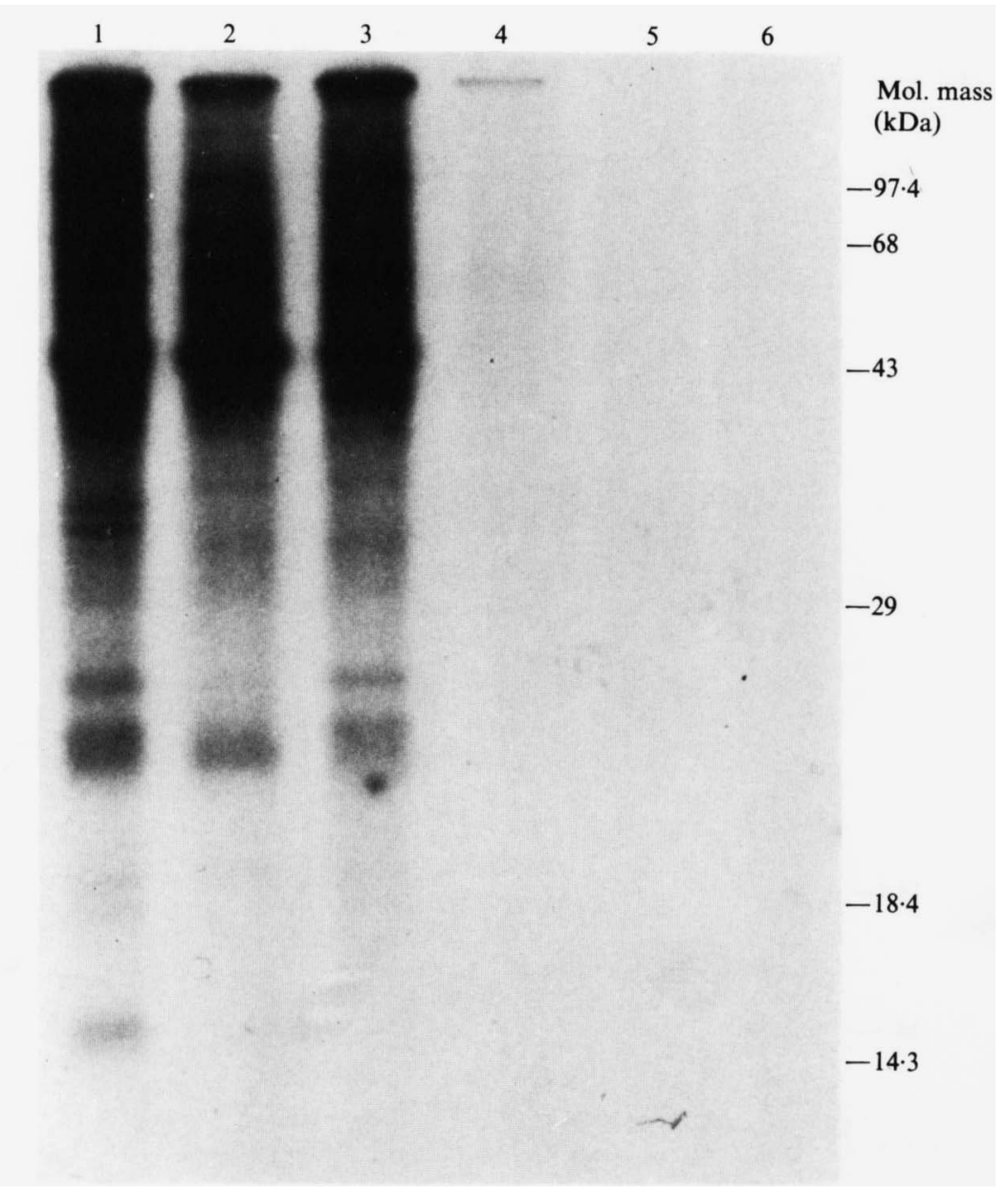

Fig. 3. Effects of $\mathrm{Ca}^{2+}$ antagonists on protein phosphorylation in germinating conidia of $M$. anisopliae. Autoradiographs of ${ }^{32} \mathrm{P}$ incorporation into proteins of conidia incubated for $10 \mathrm{~h}$ at $27^{\circ} \mathrm{C}$ in (1) unmodified YEM; (2) YEM containing $\mathrm{H}-7(50 \mu \mathrm{M})$; (3) $\mathrm{Br}-\mathrm{A} 23187(10 \mu \mathrm{M})+\mathrm{CaCl}_{2}$ (1 mM); (4) $\mathrm{Br}-\mathrm{A} 23187(10 \mu \mathrm{M})+$ EGTA $(5 \mathrm{mM}) ;(5) \mathrm{La}\left(\mathrm{NO}_{3}\right)_{3}(50 \mu \mathrm{M}) ;(6) \mathrm{R} 24571$ (2 $\left.\mu \mathrm{M}\right)$. Proteins $(30 \mu \mathrm{g})$ were subjected to SDS-PAGE $(13 \%, \mathrm{w} / \mathrm{v}$, acrylamide $)$ and autoradiographed.

Table 2. Effect of $\mathrm{Ca}^{2+}$ antagonists on protease production by $\mathrm{M}$. anisopliae after $3 \mathrm{~h}$ in medium containing chitin $(0 \cdot 2 \%)$

Values are means of three replicates $\pm \mathrm{SD}$. The results are representative of two similar experiments.

Inhibitor*

\section{None}

EGTA (5 mM)

$\mathrm{Br}-\mathrm{A} 23187(6 \mu \mathrm{M})$

Br-A23187 (6 $\mu \mathrm{M})+$ EGTA (5 mM)

$\mathrm{Br}-\mathrm{A} 23187(6 \mu \mathrm{M})+\mathrm{Ca}^{2+}(1 \mathrm{mM})$

$\mathrm{La}\left(\mathrm{NO}_{3}\right)_{3}(50 \mu \mathrm{M})$

R24571 $\left(10 \mu \mathrm{g} \mathrm{ml}^{-1}\right)$

Compound $48 / 80\left(10 \mu \mathrm{g} \mathrm{ml}^{-1}\right)$
Prl production (nmol $p$-nitroanilide hydrolysed $\mathrm{ml}^{-1} \mathrm{~min}^{-1}$ )

$$
\begin{gathered}
13.2 \pm 1.23 \\
12.8 \pm 1.28 \\
10.4 \pm 1.84 \\
0.3 \pm 0 \\
9.5 \pm 1.55 \\
2.3 \pm 0.2 \\
13.0 \pm 0.6 \\
11.6 \pm 1.3
\end{gathered}
$$

* Nifedipine, H-7 and H-8 were also tested and found to be without effect on Prl synthesis. 


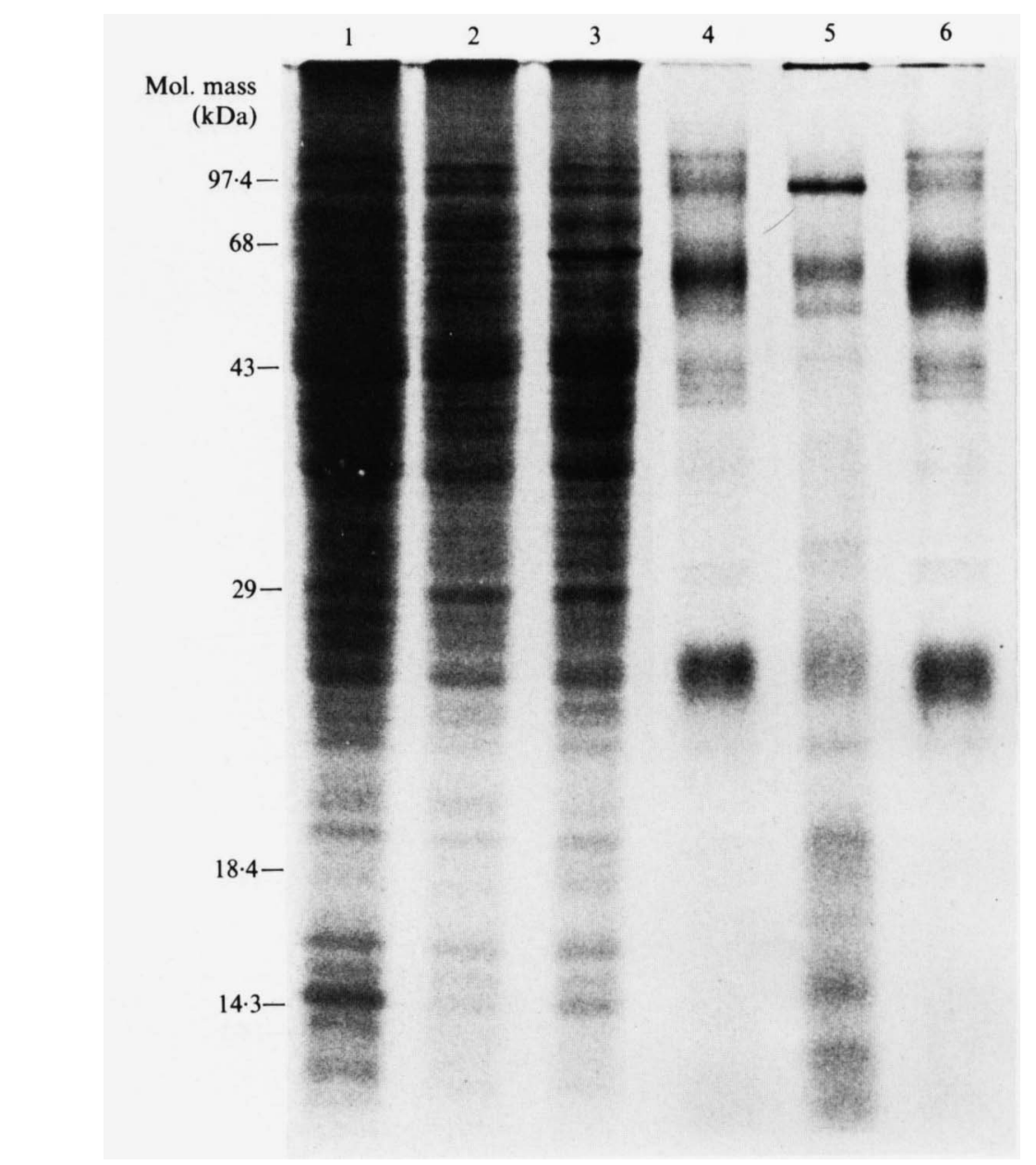

Fig. 4. Effects of $\mathrm{Ca}^{2+}$ antagonists on protein synthesis and secretion by mycelia of $M$. anisopliae. Autoradiograph of $\left[{ }^{35} \mathrm{~S}\right]$ methionine incorporation during protein synthesis $(1-3)$ and secretion $(4-6)$ by mycelia incubated for $5 \mathrm{~h}$ at $27^{\circ} \mathrm{C}$ in $(1,4)$ unmodified chitin $(0.2 \%)$ media; $(3,5)$ chitin media supplemented with Br-A23187 (10 $\mu \mathrm{M})$ + EGTA $(5 \mathrm{mM}) ;(2,6)$ R24571 (2 $\mu \mathrm{M})$. Proteins $(30 \mu \mathrm{g})$ were subjected to SDS-PAGE and autoradiographed.

higher than those required to inhibit germination (Table 2). In contrast, levels of extracellular Prl were greatly reduced by depleting or antagonizing intracellular $\mathrm{Ca}^{2+}$ using Br-A23187 + EGTA or $\mathrm{La}^{3+}$, respectively.

In spite of the effect of $\mathrm{Ca}^{2+}$ depletion on extracellular levels of $\operatorname{Pr} 1$, the profile of protein synthesis in mycelia determined after incubation with $\left[{ }^{35}\right.$ S $]$ methionine was almost unaffected by Br-A23187 + EGTA or R24571 (Fig. 4). However, $\mathrm{Ca}^{2+}$ depletion reduced extracellular release of several high molecular mass proteins and a $25 \mathrm{kDa}$ band previously shown to be $\operatorname{Pr} 1$ by Western blot analysis (St Leger et al., 1989b), while increasing the release of lower molecular mass polypeptides (Fig. 4). This was not due to a toxic effect by Br-A23187 or EGTA as these agents did not affect the profile of protein secretion when applied separately.

\section{Effect of $\mathrm{Ca}^{2+}$ antagonists on phosphorylation of proteins during $\mathrm{Pr} 1$ synthesis}

Incubation of mycelia for $1 \mathrm{~h}$ in chitin media allowed phosphorylation of at least 40 proteins (Fig. 5). Treating mycelia with $\mathrm{Br}-\mathrm{A} 23187+$ EGTA or $\mathrm{La}^{3+}$ produced sharp decreases in net phosphorylation (Fig. 5 and data not shown). Elevating cytoplasmic $\mathrm{Ca}^{2+}$ with a combination of 


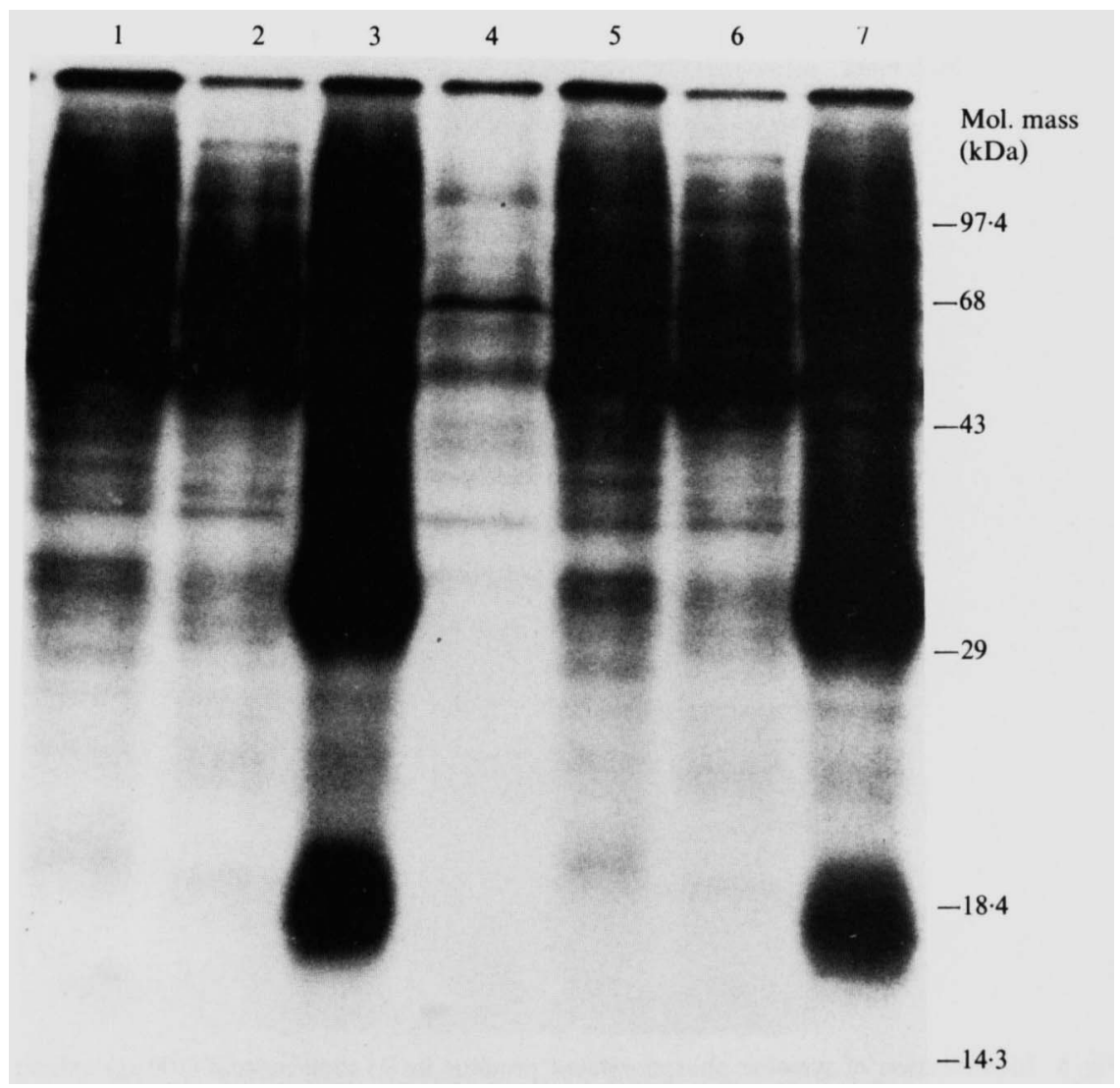

Fig. 5. Effects of $\mathrm{Ca}^{2+}$ antagonists on protein phosphorylation in mycelia of $M$. anisopliae. Autoradiograph of ${ }^{32} \mathrm{P}$ incorporation into proteins of mycelia incubated for $1 \mathrm{~h}$ at $27^{\circ} \mathrm{C}$ in (1) unmodified chitin $(0.2 \%)$ media; (2) chitin media containing H-7 (50 $\mu \mathrm{M})$; (3) R24571 (2 $\mu \mathrm{M})$; (4) $\mathrm{Br}-\mathrm{A} 23187(10 \mu \mathrm{M})+\mathrm{EGTA}(5 \mathrm{mM})+\mathrm{R} 24571 \quad(2 \mu \mathrm{M})$; (5) Br-A23187 (10 $\mu \mathrm{M})$; (6) Br-A23187 $(10 \mu \mathrm{M})+\mathrm{CaCl}_{2}(1 \mathrm{mM})+\mathrm{H}-7(50 \mu \mathrm{M}) ;(7) \mathrm{Br}-\mathrm{A} 23187(10 \mu \mathrm{M})+\mathrm{CaCl}_{2}(1 \mathrm{mM})+\mathrm{R} 24571 \quad(2 \mu \mathrm{M})$. Proteins $(30 \mu \mathrm{g})$ were subjected to SDS-PAGE $(13 \%, \mathrm{w} / \mathrm{v}$, acrylamide) and autoradiography.

$\mathrm{Br}-\mathrm{A} 23187+\mathrm{Ca}^{2+}(1 \mathrm{mM})$ did not affect phosphorylation. In spite of repressing Prl production, addition of nutrients $(1 \%$ alanine $+1 \%$ glucose $)$ had no detectable effect on the phosphorylation profile (data not shown).

$\mathrm{CaM}$ antagonists ( $\mathrm{R} 24571)$ increased $\left[{ }^{32} \mathrm{P}\right]$ orthophosphate incorporation into 17 and $33 \mathrm{kDa}$ proteins (Fig. 5) as did compound $48 / 80$ (data not shown). This effect was not inhibited by cycloheximide indicating that de novo synthesis of substrate is not required. However, $\mathrm{Ca}^{2+}$ depletion (Br-A23187 + EGTA) over-rode the enhancing effect of $\mathrm{CaM}$ antagonists indicating that radiolabelling is $\mathrm{Ca}^{2+}$ dependent.

The involvement of the C-kinase pathway was tested with the C-kinase activator TPA and the inhibitor H-7 (Hidaka \& Tanaka, 1987). While TPA had no effect (data not shown), H-7 at high concentrations $(>100 \mu \mathrm{M})$ repressed phosphorylation of a $27 \mathrm{kDa}$ protein (Fig. 5). A similar effect was produced by H-8 (inhibitor of cyclic-nucleotide-dependent kinase) so the form of control of the responsible kinase is in doubt.

\section{Phosphoamino acid analysis}

Proteins from mycelia preincubated with $\left[{ }^{32} \mathrm{P}\right]$ phosphoric acid were analysed by SDS-PAGE and the gel incubated in $1 \mathrm{M}-\mathrm{NaOH}$ at $55^{\circ} \mathrm{C}$ for $1 \mathrm{~h}$ prior to autoradiography. This eliminates phosphate present on serine and threonine residues but not on tyrosine residues (Cooper $\&$ 


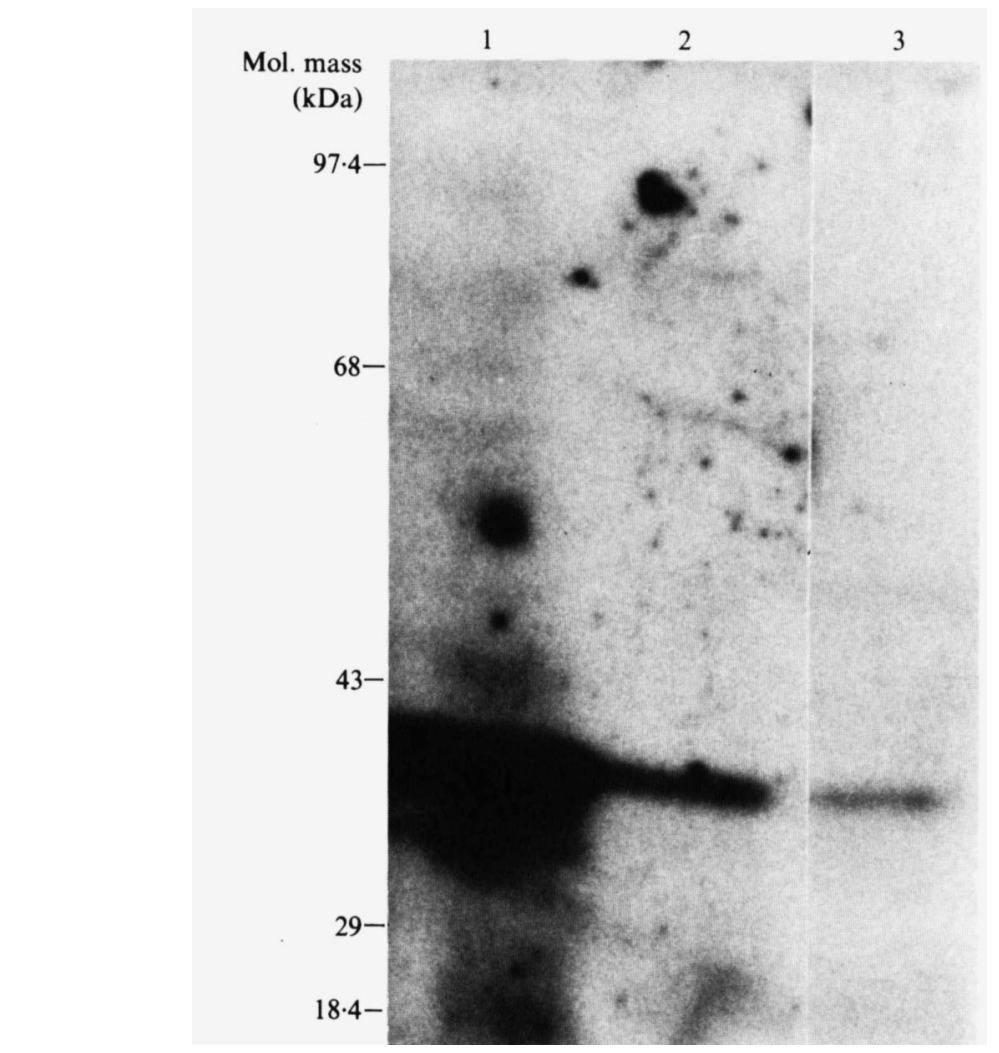

Fig. 6. Identification of tyrosine phosphorylated proteins in (1) total protein $(100 \mu \mathrm{g})$ extract from mycelia; (2) proteins solubilized from plasma membranes by $10 \mathrm{mM}-\mathrm{Tris} / \mathrm{HCl}(\mathrm{pH} 7 \cdot 5)$ supplemented with $0.1 \%$ Triton X-100; (3) $10 \mathrm{~mm}$-Tris/HCl $(\mathrm{pH} \mathrm{7.5)}$ alone. Proteins were subjected to SDS-PAGE $(13 \%, w / v$, acrylamide), electroblotted on to nitrocellulose, probed with anti-PTYR-bodies and ${ }^{125} \mathrm{I}$-protein $\mathrm{A}$ and autoradiographed.

Hunter, 1981). Most of the radiolabel was removed by this treatment and the few remaining bands were almost indistinct against a high background (data not shown). Therefore, most of the proteins are phosphorylated at serine and threonine residues.

Immunoblotting total cellular proteins with anti-PTYR (Wang, 1988) revealed prominent bands at 38 and $34.5 \mathrm{kDa}$, and minor bands of higher molecular mass (Fig. 6). The predominant $38 \mathrm{kDa}$ protein could also be identified on isolated plasma membranes. Partial disruption of the membrane structure by preincubation with Triton X-100 solubilized more of the $38 \mathrm{kDa}$ protein than washing with buffer alone (Fig. 6). Phosphorylation at tyrosine was unaffected by growing the mycelia in a nutrient rich medium $(0.2 \%$ chitin, $1 \%$ alanine and $1 \%$ glucose) versus chitin $(0.2 \%)$ alone or preincubation of mycelia $(5 \mathrm{~h})$ with $\mathrm{Br}-\mathrm{A} 23187+\mathrm{CaCl}_{2}$ or EGTA, R24571, H-7, $\mathrm{H}-8$ or cAMP.

\section{DISCUSSION}

Germination of conidia of $M$. anisopliae requires uptake of nutrients and involves de novo synthesis of protein (Dillon \& Charnley, 1989; St Leger et al., 1989a). Uptake of [ ${ }^{35}$ S]methionine or [ ${ }^{32} \mathrm{P}$ ] fulfill essential criteria for $\mathrm{Ca}^{2+} / \mathrm{CaM}$-dependent processes (Cheung, 1980). Thus CaM and $\mathrm{CaM}$ target-proteins were detected in ungerminated conidia. Also, depleting intracellular $\mathrm{Ca}^{2+}$, or treatment with CaM antagonists massively reduced uptake of both isotopes, indicative of a non-specific inhibition of nutrient uptake. By contrast, inhibitors of C-kinase and cyclic- 
nucleotide-dependent kinases affected individual phosphorylation events without altering net phosphorylation, protein synthesis and germination.

The presence of CaM and the same CaM target-proteins in both ungerminated conidia and germlings indicates that the machinery for $\mathrm{CaM}$ activation of germination-related processes exists preformed before germination and therefore does not require de novo protein synthesis. $\mathrm{CaM}$ levels in conidia and mycelia were similar (about $0.3 \%$ of total proteins assuming a quantitatively similar response being given by $\mathrm{CaM}$ from $M$. anisopliae and from rat) indicating little if any increase in $\mathrm{CaM}$ synthesis relative to the total protein during germination and growth. This is in contrast to higher plants where CaM levels fluctuate markedly during growth and differentiation (Cocucci \& Negrini, 1988). Furthermore, the number and concentration of $\mathrm{CaM}$-binding proteins was similar in conidia and germlings. Work on mammalian systems has demonstrated a close relationship between $\mathrm{CaM}$ concentrations and those of its target proteins which enables $\mathrm{CaM}$ to modulate the effect of the $\mathrm{Ca}^{2+}$ signal (Klee \& Newton, 1985).

As $\mathrm{CaM}$ is activated by $\mathrm{Ca}^{2+}$, its effect on germination events may be linked with mobilization of intracellular $\mathrm{Ca}^{2+}$ reserves. Consistent with this, depletion of intracellular $\mathrm{Ca}^{2+}$ or treatment with $\mathrm{La}^{3+}$ duplicated the effects of $\mathrm{R} 24571$. Inhibition by $\mathrm{La}^{3+}$ but not by fluorescein isothiocyanate or ryanodine implies that the $\mathrm{Ca}^{2+}$ is derived from mitochondrial stores rather than the endoplasmic reticulum (Reid \& Bygraves, 1974; Mitchinson et al., 1982; Nagasaki \& Fleischer, 1988). This is consistent with the known ultrastructure of Metarhizium conidia which contain large mitochondria but little endoplasmic reticulum (Dillon \& Charnley, 1989). However, $\mathrm{La}^{3+}$ can compete with $\mathrm{Ca}^{2+}$ for many binding sites including those on the surface of the cell and it may affect physiology in different ways (Anghileri, 1987).

A precise knowledge of how $\mathrm{CaM}$ functions in initiating germination awaits identification of the CaM-binding proteins. That several CaM-binding proteins were detected in conidia and germlings is strong evidence that $\mathrm{CaM}$ is a multifunctional regulator. However, the massive repression of [ ${ }^{32} \mathrm{P}$ ]orthophosphate uptake and phosphorylation both by $\mathrm{Ca}^{2+}$ depletion and treatment with $\mathrm{R} 24571$ is indicative of action by $\mathrm{Ca}^{2+} / \mathrm{CaM}$-dependent protein kinase(s), the primary mechanism of CaM action in other systems (Nairn et al., 1985). Similarities in overall protein composition between conidia and germlings (St Leger et al., 1989b) and the fact that most proteins identified by Coomassie blue staining were also detectable using $\left[{ }^{35}\right.$ S $]$ methionine as a precursor suggests that kinase activity would not require de novo synthesis of protein substrates. As germination and protein synthesis can take place without nuclear division and in the presence of hydroxyurea, an inhibitor of DNA synthesis (St Leger et al., 1989a), inhibition of nuclear division by $\mathrm{CaM}$ antagonists is unlikely to be involved in repression of protein synthesis.

$\mathrm{CaM}$ antagonists do not inhibit incorporation of isotopes into proteins, and extracellular secretion of proteins by mycelia over a $3 \mathrm{~h}$ period. Thus the continuous activity of CaM may not be required after protein synthesis is initiated. Furthermore, initiation of the synthesis of $\operatorname{Pr} 1$ is not affected by $\mathrm{CaM}$ inhibitors. Therefore $\mathrm{CaM}$ is not involved in the regulation of at least one protein produced post-germination. The effect of $\mathrm{CaM}$ antagonists in selectively enhancing ${ }^{32} \mathrm{P}$ incorporation into 17 and $33 \mathrm{kDa}$ polypeptides suggests the existence of a CaM-stimulated phosphatase as reported in vertebrates (Nairn et al., 1985).

The lack of inhibition of net phosphorylation in mycelia by CaM antagonists or the C-kinase inhibitor $\mathrm{H}-7$ indicates that the repression of phosphorylation produced by $\mathrm{Ca}^{2+}$ deletion or antagonism ( $\mathrm{La}^{3+}$ addition) may have resulted directly from $\mathrm{Ca}^{2+}$ perturbation. $\mathrm{Ca}^{2+}$ dependent, $\mathrm{CaM}$-independent kinases are known in plants (Hetherington \& Trewavas, 1984) and several proteins besides $\mathrm{C}$-kinase and $\mathrm{CaM}$ can mediate the effect of $\mathrm{Ca}^{2+}$ in different systems (Carafoli, 1987). $\mathrm{Ca}^{2+}$ depletion did not prevent protein synthesis so the effect on phosphorylation may be quite specific rather than due to gross disruption of membrane processes dependent on $\mathrm{Ca}^{2+}$ gradients.

We were unable to correlate $\operatorname{Prl}$ production with a single phosphorylation event. Catabolite repression of $\mathrm{Pr} 1$ synthesis had little effect on the phosphorylation profile, while $\mathrm{Ca}^{2+}$ depletion and $\mathrm{La}^{3+}$ repressed both $\mathrm{Pr} 1$ secretion and net phosphorylation. In many systems, $\mathrm{Ca}^{2+}$ plays an important role in enzyme release by exocytosis (Knight, 1986). 
Immunoblot detection of tyrosine phosphorylation revealed two major bands (38 and $34.5 \mathrm{kDa}$ ). Compared to the ${ }^{32} \mathrm{P}$ autoradiographs, these phosphoproteins do not belong to the major phosphorylated proteins which are all alkali susceptible. Thus phosphotyrosine is a scarce residue in $M$. anisopliae, as well as some other systems (Hirsch-Behnam \& Barnekow, 1988). Phosphotyrosine has been detected in yeast proteins and a plasma-membrane preparation was shown to produce alkali-resistant phosphorylation of casein (Castellanos \& Mazon, 1985). Similarly, a component of the major tyrosine phosphoprotein is localized on the plasma membrane. This is significant as tyrosine kinases catalyse autophosphorylation and are recognized by anti-PTYR antibody (Pilch, 1989). Tyrosine kinase in vertebrate systems is often intrinsic to surface receptors, ligand-receptor interactions leading directly to protein phosphorylation of tyrosine without the requirement for intermediary messengers (McNeil \& Taylor, 1987). These phosphorylation events are consequently unresponsive to $\mathrm{Ca}^{2+}$ and cAMP as reported here for $M$. anisopliae. By analogy tyrosine-specific protein kinases could themselves be important mediators of primary messages in $M$. anisopliae.

The data on $\mathrm{Ca}^{2+}$-promoted protein phosphorylation indicates that $\mathrm{Ca}^{2+}$ has an important role in regulating phosphorylation at threonine and serine residues. Furthermore, $\mathrm{CaM}$ acts as a $\mathrm{Ca}^{2+}$ effector in conidia where its activity is crucial for protein synthesis and germination. While there is strong evidence for pathways for the transduction of stimuli in this fungus that involve $\mathrm{Ca}^{2+}$ and $\mathrm{CaM}$ similar to those known in plant and animal systems, additional research will be required to elucidate the nature of the protein kinases and their substrates to understand how $\mathrm{Ca}^{2+}$ fluxes activate cell metabolism.

This work was supported in part by a grant from the Cornell Biotechnology Program which is sponsored by the New York State Science and Technology Foundation, a consortium of industries and the US Army Research Office.

\section{REFERENCES}

ANGHILERI, L. J. (1987). Calcium and cell death. In The Role of Calcium in Biological Systems, vol. 4, pp. 191216. Edited by L. J. Anghileri. Boca Raton, Florida: CRC Press.

Asano, M. \& StUll, J. T. (1985). Effects of calmodulin antagonists on smooth muscle contraction and myosin phosphorylation. In Calmodulin Antagonists and Cellular Physiology, pp. 225-260. Edited by $\mathbf{H}$. Hidaka \& D. J. Hartshorne. New York: Academic Press.

Asano, M., Tanaka, T. \& Hidaka, H. (1985). Calmodulin antagonists as inhibitors of platelet aggregation and secretion. In Calmodulin Antagonists and Cellular Physiology, pp. 261-272. Edited by $\mathbf{H}$. Hidaka \& D. J. Hartshorne. New York: Academic Press.

Billingsley, M. L., Pennypacker, K. R., Hoover, C. G., Brigati, D. J. \& KinCaid, R. L. (1985). A rapid and sensitive method for the detection and quantification of calcineurin and calmodulin-binding proteins using biotinylated calmodulin. Proceedings of the National Academy of Sciences of the United States of America 82, 75857589.

Borgeson, C. E. \& Bowman, B. J. (1983). Isolation and characterization of the Neurospora crassa endoplasmic reticulum. Journal of Bacteriology 156, 362-368.

Bowman, E. J. \& Bowman, B. J. (1988). Purification of vacuolar membrane, mitochondria and plasma membranes from Neurospora crassa and modes of discriminating among the different $\mathrm{H}^{+}$-ATPases. Methods in Enzymology 157, 562-573.
Bradford, M. M. (1976). A rapid and sensitive method for the quantitation of microgram quantities of protein utilizing the principle of protein-dye binding. Analytical Biochemistry 72, 248-254.

BuRNETTE, W. N. (1981). 'Western blotting': electrophoretic transfer of proteins from sodium dodecyl sulfate-polyacrylamide gels to unmodified nitrocellulose and radiographic detection with antibody and radioiodinate protein A. Analytical Biochemistry 112, 195-203.

CARAFoli, E. (1987). Intracellular calcium homeostasis. Annual Review of Biochemistry 56, 395-433.

Castellanos, R. M. P. \& Mazón, M. J. (1985). Identification of phosphotyrosine in yeast proteins and of a protein tyrosine kinase associated with the plasma membrane. Journal of Biological Chemistry 260, 8240-8242.

CHEUNG, W. Y. (1980). Calmodulin plays a pivotal role in cellular regulation. Science 207, 19-27.

Cocucci, M. \& Negrini, N. (1988). Changes in the levels of calmodulin and of a calmodulin inhibitor in the early phases of radish (Raphanus sativus L.) seed germination. Plant Physiology 88, 910-914.

COHEN, P. (1982). The role of protein phosphorylation in neural and hormonal control of cellular activity. Nature, London 296, 613-620.

COHEN, P. (1985). The role of protein phosphorylation in the hormonal control of enzyme activity. European Journal of Biochemistry 151, 439-448.

COOPER, J. \& HUNTER, T. (1981). Changes in protein phosphorylation in Rous sarcoma virus-transformed chicken embryo cells. Molecular and Cellular Biology 1, 165-178. 
Deber, C. M., Tom-Kun, J., Mack, E. \& Grinstein, S. (1985). Bromo-A23187: a nonfluorescent calcium ionophore for use with fluorescent probes. Analytical Biochemistry 146, 349-352.

Dillon, R. J. \& ChaRnley, A. K. (1989). Initiation of germination in conidia of the entomopathogenic fungus Metarhizium anisopliae. Experimental Mycology (in the Press).

EILAM, Y. \& ChERNICHOVSKY, D. (1988). Low concentrations of trifluoperazine arrest the cell division cycle of Saccharomyces cerevisiae at two specific stages. Journal of General Microbiology 134, 1063-1069.

FAVRe, B. \& TURIAN, G. (1987). Identification of a calcium- and phospholipid-dependent protein kinase (protein kinase C) in Neurospora crassa. Plant Science 49, 15-21.

Giannini, J. L., Holt, J. S. \& BRiskin, D. P. (1988). Isolation of sealed plasma membrane vesicles from Phytophthora megasperma f. sp. glycinea. II. Partial characterization of $\mathrm{Ca}^{2+}$ transport and glyceollin effects. Archives of Biochemistry and Biophysics 266, 644-649.

Goffeau, A. \& Slayman, C. W. (1981). The protein translocating ATPase of the fungal plasma membrane. Biochimica et biophysica acta 634, 197-223.

HePleR, P. K. \& WAYNe, R. O. (1985). Calcium and plant development. Annual Review of Plant Physio$\log y 36,397-439$.

Hetherington, A. M. \& Trewavas, A. (1984). Activation of a pea membrane protein kinase by calcium ions. Planta 161, 409-417.

Hidaka, H. \& TANAKA, T. (1987). Transmembrane $\mathrm{Ca}^{2+}$ signaling and a new class of inhibitors. Methods in Enzymology 139, 570-582.

Hirsch-Behnam, A. \& Barneckow, A. (1988). Characterization of phosphoproteins in sponge cells. Comprehensive Biochemistry and Physiology 41B, 125-131.

Jones, P. M., Salmon, D. M. W. \& Howell, S. L. (1988). Protein phosphorylation in electrically permeabilized islets of Langerhans. Biochemical Journal 254, 397-403.

Kamps, M. P. \& Sefton, B. M. (1988). Identification of multiple novel polypeptide substrates of the v-src, v-yes, v-fps, v-ros, and v-erbB oncogenic tyrosine protein kinases utilizing antisera against phosphotyrosine. Oncogene 2, 305-315.

KLEE, C. B. \& Newton, D. L. (1985). Calmodulin: an overview. In Control and Manipulation of Calcium Movement, pp. 131-146. Edited by J. R. Parratt. New York: Raven Press.

KNIGHT, D. E. (1986). Calcium and exocytosis. In Calcium and the Cell, pp. 250-270. Edited by D. Evered \& J. Whelan. Chichester: John Wiley.

Krebs, E. G. \& Beavo, J. A. (1979). Phosphorylationdephosphorylation of enzymes. Annual Review of Biochemistry 48, 923-959.

LAEMMLI, U. K. (1970). Cleavage of structural proteins during the assembly of the head of bacteriophage T4. Nature, London 227, 680-684.

McNeil, P. L. \& TAYloR, D. L. (1987). Early cytoplasmic signals and cytoskeletal responses initiated by growth factors in cultured cells. In Cell Membranes, Methods and Reviews, vol. 3, pp. 365405. Edited by E. Elson, W. Frazier \& L. Glaser. New York: Plenum Press.
Maniatis, T., Fritsch, E. F. \& SambrooK, J. (1982). Molecular Cloning : a Laboratory Manual, pp. 194195. Cold Spring Harbor, NY: Cold Spring Harbor Laboratory.

Mitchinson, C., Wilderspin, A. F., Trinnaman, B. J. \& GREEN, N. M. (1982). Identification of a labelled peptide after stoicheiometric reaction of fluorescein isothiocyanate with the $\mathrm{Ca}^{2+}$-dependent adenosine triphosphatase of sarcoplasmic reticulum. FEBS Letters 146, 87-92.

Muthukumar, G., Nickerson, A. W. \& Nickerson, K. W. (1987). Calmodulin levels in yeasts and filamentous fungi. FEMS Microbiology Letters 41, 253-255.

Nagasaki, K. \& Fleischer, S. (1988). Ryanodine sensitivity of the calcium release channel of sarcoplasmic reticulum. Cell Calcium 9, 1-7.

Nairn, A. C., Hemmings, H. C., JR \& Greengard, P. (1985). Protein kinases in the brain. Annual Review of Biochemistry 54, 931-976.

Nestler, E. J., Walaas, S. I. \& Greengard, P. (1984). Neuronal phosphoproteins: physiological and clinical implications. Science 225, 1357-1364.

Ortega Perez, R., Van Tuinen, D., Marmé, D. \& Turian, G. (1981). Purification and identification of calmodulin from Neurospora crassa. FEBS Letters 133, 205.

Ortega Perez, R., Van Tuinen, D., Marmé, D. \& TURIAN, G. (1983). Calmodulin-stimulated cyclic nucleotide phosphodiesterase from Neurospora crassa. Biochimica et biophysica acta 758, 84-87.

PILCH, P. F. (1989). The IGF-I receptor kinase. In Receptor Phosphorylation, pp. 135-148. Edited by V. K. Moudgil. Boca Raton, Florida: CRC Press.

ReID, K. C. \& Bygraves, F. L. (1974). The inhibition of mitochondrial calcium transport by lanthanides and ruthenium red. Biochemical Journal 140, 143145.

Roufogalis, B. D., Minocherhomjee, A. E. V. M. \& AL-JoBORE, A. (1983). Pharmacological antagonism of calmodulin. Canadian Journal of Cell Biology 61, 927-933.

Schmid, J. \& Harold, F. M. (1988). Dual roles for calcium ions in apical growth of Neurospora crassa. Journal of General Microbiology 134, 2623-2631.

Serrano, R. (1978). Characterization of the membrane ATPase of Saccharomyces cerevisiae. Molecular and Cellular Biochemistry 22, 51-62.

Sibley, D. R., Benvoic, J. L., Caron, M. G. \& LEFKOWITZ, R. J. (1987). Regulation of transmembrane signaling by receptor phosphorylation. Cell 48, 913-922.

St Leger, R. J., Charnley, A. K. \& CoOper, R. M. (1987). Characterization of cuticle degrading proteases produced by the entomopathogen Metarhizium anisopliae. Archives of Biochemistry and Biophysics 253, 221-232.

St Leger, R. J., Durrands, P. K., Charnley, A. K. \& COOPER, R. M. (1988). The role of extracellular chymo-elastase in the virulence of Metarhizium anisopliae for Manduca sexta. Journal of Invertebrate Pathology 52, 285-293.

St Leger, R. J., ButT, T. M., Roberts, D. W. \& Staples, R. C. (1989a). Production in vitro of appressoria by the entomopathogenic fungus Metarhizium anisopliae. Experimental Mycology (in the Press). 
St Leger, R. J., Butt, T. M., Staples, R. C. \& ROBERTS, D. W. $(1989 b)$. Synthesis of proteins including a cuticle-degrading protease during differentiation of the entomopathogenic fungi Metarhizium anisopliae. Experimental Mycology (in the Press).
Van Tuinen, D., Ortega Perez, R., Marmé, D. \& TURIAN, G. (1984). Calcium calmodulin-dependent protein phosphorylation in Neurospora crassa. FEBS Letters 317-320.

WANG, J. Y. J. (1988). Antibodies for phosphotyrosine. Analytical Biochemistry 172, 1-7. 